\title{
First recorded case of haemoglobin SC in sudan
}

\author{
Abozer Y. Elderdery ${ }^{1 *}$, Babiker A Mohamed ${ }^{2}$, Samiah Hamad AL- Mijalli ${ }^{3}$ and Jeremy Mills ${ }^{4}$ \\ *Correspondence: abozer904@hotmail.com C CrossMark \\ 'Department of Haematology, College of Applied Medical Sciences, Aljouf University, Saudi Arabia. \\ ${ }^{2}$ Specialization Board, Khartoum, Sudan. \\ ${ }^{3}$ Department of microbiology, Princess Nora bint Abdulrahman University in Riyadh Princess Nora \\ bint Abdulrahman University in Riyadh. \\ ${ }^{4}$ School of Pharmacy and Biomedical Sciences, Portsmouth University, UK.
}

\begin{abstract}
A haemoglobin $(\mathrm{Hb})$ disorder was the first polymorphism suggested to have a relationship with malaria, as $\mathrm{Hb} \mathrm{S}$ and $\mathrm{C}$ offer a survival advantage in malarial endemic regions. Two schoolgirls aged 11 and 16 were admitted to the Military Hospital in Omdurman on the $2^{\text {nd }}$ of April 2009. They had Hb (haemoglobin) SC and their parents were carriers of abnormal Hb; the mother was (HbAS) and father $(\mathrm{HbAC})$. These girls were the first reported cases of HbSC in Sudan. Capillary Electrophoresis (CE) was initially used to determine the $\mathrm{Hb}$ type. CE-High Performance Liquid Chromatography (CE-HPLC) was used as a confirmatory test. A new type of abnormal Hb in Sudan is not unexpected, because is of its wide tribal diversity. Additionally, Sudan is a high malarial region and a new Hb variant is likely to be discovered.

Keywords: $\mathrm{Hb} \mathrm{S}$ and $\mathrm{C}$, haemoglobinopathies management and population
\end{abstract}

\section{Introduction}

Haemglobin $(\mathrm{Hb}) \mathrm{S}\left(a_{2} \beta_{2}{ }^{6 g l u} \rightarrow\right.$ val $)$ and $\mathrm{HbC}\left(a_{2} \beta_{2}{ }^{6 g l u} \rightarrow\right.$ Lys $)$ are autosomal recessive disorders with a mutation in the $\beta$ globin gene. They have the same substitution at the $6^{\text {th }}$ position of the $\beta$-globin chain, however, their amino acid types differ, as $\mathrm{Hb} \mathrm{S}$ is an abnormal $\mathrm{Hb}$ with substitution of valine (Val) for glutamic acid (Glu), whereas $\mathrm{Hb} \mathrm{C}$ is an abnormal $\mathrm{Hb}$ with substitution of (Lys) for Glu [1]. Despite being a small change, it can cause disastrous complications [2]. These abnormal variants may be found in a double heterozygous form HbSC and cause (HbSC disease), but at a lower incidence. Individuals with HbSC disease have atypical haemolytic anaemias and sickling also occurs. Individuals with $\mathrm{HbSC}$ have been found to be more at risk for renal papillary necrosis, retinopathy and thrombotic complications than patients with sickle cell trait (SCT) [3]. However, the complications in patients with HbSC are lower than those with $\mathrm{HbSS}$. Internationally, approximately $4.5 \%$ of the world population carry $\mathrm{Hb}$ disorders [4], with most detected in parts of Africa, particularly $\mathrm{Hb} \mathrm{S}$ which is found most frequently in equatorial Africa and in people of African descent [5]. In contrast, the highest prevalence of $\mathrm{Hb} \mathrm{C}$ is in the West coast of Africa [6] where approximately $0.3 \%$ of children are heterozygous for $\mathrm{HbAC}$ and homozygous $\mathrm{HbCC}$ occurs in approximately 1 in 5,000 births in that population [7]. $\mathrm{Hb} \mathrm{C}$ is either homozygous or heterozygous as in $\mathrm{HbCC}$ or $\mathrm{HbAC}$, respectively, or it can be compounded with another $\mathrm{Hb}$ abnormality, such as HbSC [3].

The geographic coincidence of $\mathrm{HbS}$ and $\mathrm{C}$ genes is well reported in regions where malaria is endemic $[8,9]$. Geographically, Sudan is situated in the centre of Africa, with a high prevalence of malaria [10]. Hb variants and Malaria are also known to be prevalent in the Khartoum area $[11,12]$, as it has variety in its populations accompanied by variation in $\mathrm{Hb}$ phenotypes $[13,14]$. Therefore, different types of $\mathrm{Hb}$ variants are not unexpected to emerge in Khartoum, because in 1967 a published study showed a new $\mathrm{Hb}$ like $\mathrm{HbSO}^{\text {Arab }}$ [15]. Therefore, a new type of abnormal $\mathrm{Hb}$ is anticipated among the Sudanese.

Electrophoresis, CE-HPLC, Iso Electric Focusing (IEF) and DNA analysis are the main methods for detecting haemoglobinopathies. Obtaining family history and full blood count (FBC) are also an important factor in gaining a fuller picture of the cases. Medical history within the family is particularly important in communities, where consanguineous marriage is preferred $[16,17]$. Awareness of these issues within communities will help to prevent carrier parents having children with the disease.

At present, no study exists on the effect of $\mathrm{Hb}$ variants within the Sudanese population, as a result of migrating populations into Khartoum. This is because there is no multidisciplinary approach to managing haemoglobinopathy in the area. Therefore, this study illustrates the hypotheses that new types of $\mathrm{Hb}$ may be discovered in Sudan due to the ethnic diversity there.

\section{Materials and methods}

Ethical approval was obtained for the study and written informed consent was given by the family guardian. Initially, interviews 
Elderdery et al. Hematology and Leukemia 2014,

and questionnaires were used to collect demographics: age, sex, ethnicity (tribe) and family history. A total of 6 subjects representing a Sudanese family were recruited from Khartoum military Hospital.

$5 \mathrm{ml}$ of venous blood with $\mathrm{K}_{2}$-EDTA (anti coagulant) were collected from each participant and delivered to the haematology laboratory at the Military Hospital, Khartoum. Each sample was processed as follows:

Firstly, FBC and Capillary electrophoresis (CE) were used to diagnose all participants. FBC was performed in a fully automated machine (Sysmex NE-800 analyzer; Toa Medical Electronics, Kobe, Jaban). CE was performed in completely automatic equipment (Cebia-Model 2007). Control samples were prepared using a mixture of $\mathrm{Hbs} \mathrm{A}, \mathrm{F}, \mathrm{S}$ and $\mathrm{C}$ and included in each experiment alongside the test samples [18].

Dried specimens were then prepared from the blood samples with Guthrie cards as per instructions (Whatman UK, whatmaninfo@ge.com); i.e., a drop of blood was positioned onto the card, allowed to soak through and left to dry. Samples on Guthrie cards were stored at $-20^{\circ} \mathrm{C}$ with dessicant material to keep specimens dry. CE-HPLC was used as a confirmatory test after Capillary electrophoresis [18]. Guthrie card samples were analyzed, using CE-HPLC [19]. The equipment used was the VARIANT nbs, Bio-Rad GDM System.

\section{Results}

(Figure 1) summarized the results of CE and CE-HPLC. The former showed three zones with the mobilities of $\mathrm{Hb} C, \mathrm{~S}$ and $F$ in two sisters (A\&B) of 11 and 16 years of age with $\mathrm{HbSC}$; their brother (C) 7 years old and sister (D) aged 13 were heterozygous $\mathrm{HbAS}$. Their parents yielded heterozygous forms, the mother of 38 years of age with $\mathrm{HbAS}$ and father of 52 with $\mathrm{HbAC}$. (Figure 2) illustrates the findings using CEHPLC chromatographs. The results were exactly the same as CE without overlap.

Among the family members the $\mathrm{HbSC}$ cases had high WBC and RDW, whereas their Hb, PCV and RBC count were low. They had lymphocytosis and their neutrophils were near the lower limit of the normal range (Table 1).

$\mathrm{Hb} F$ was found at levels between (4.4 to $4.6 \%$ ) in those with $\mathrm{HbSC}, 0.2 \%$ in the mother but undetectable in the other heterozygous forms (Table 2).

\section{Discussion}

$\mathrm{Hb} \mathrm{S}$ is known to be prevalent in Sudan and was suggested to be more common in populations from Western tribes $[\mathbf{2 0 , 2 1 ]}$. On the other hand, $\mathrm{Hb} \mathrm{C}$ is not as well documented as $\mathrm{HbS}$ in Sudan, but was recently reported in 2008 [12]. Interestingly, the current study showed two schoolgirls with $\mathrm{HbSC}$, as their parents are carriers of $\mathrm{HbAS}$ and $\mathrm{HbAC}$ (Figures 1 and 2). Their family is currently living in the Khartoum area (Omdurman) but originate from Western Sudan. The parents come from different tribes; the father from the Darhamid tribe and the mother from the Taisha tribe.
This family had four children with abnormal $\mathrm{Hb}$ : two daughters with $\mathrm{HbSC}$, a daughter with $\mathrm{HbAS}$ and a son with $\mathrm{HbAS}$, as illustrated in the diagram of (Figure 3). Interestingly, half of their children are carriers, half with $\mathrm{HbSC}$ disease and none of them with normal $\mathrm{Hb}$. This is the first finding of $\mathrm{HbSC}$ among the Sudanese and as with the discovery of $\mathrm{Hb}-\mathrm{O}^{\text {Arab }}[15]$, further discoveries of new $\mathrm{Hb}$ abnormalities are expected to emerge, the supposition being that the variety in the population will be accompanied by variation in $\mathrm{Hb}$ types. Therefore, Screening and genetic counseling are required deter carrier parents from having children with abnormalities and so minimize incidence.

That no major reports exist on $\mathrm{Hb}$ variants within the Sudanese is due to the lack of technology to determine types of abnormal $\mathrm{Hb}$ e.g., CE-HPLC, IEF and molecular methods. This is due to lack of funding and the resources to identify blood disorders accurately. CE is available in parts of the country, which is accepted in conjunction with CE-HPLC or IEF as the most appropriate test for detecting $\mathrm{Hb}$ variants. The current study used the availability of CE at the Military Hospital, Omdurman, Sudan and CE-HPLC was used as a confirmatory test, using Guthrie cards in order to transport dry samples for analysis at the University of Portsmouth, UK.

The blood count parameters of SC patients in the current study were similar to sickle patients. They had high WBC and RDW and low Hb, PCV and RBC count. This is the same as reported for HbSC by Stevens and his colleagues [22]. In contrast, $\mathrm{Hb}, \mathrm{PCV}$ and $\mathrm{RBC}$ levels were low in their mother, but her RDW and WBC were normal (Table 1). The haematological parameters of their father and brother were normal, but the sister with AS had low $\mathrm{Hb}$ and PCV.

The two sisters with HbSC had lymphocytosis and their neutrophils were at the lower limit of the normal range. However, studies reported that sickle cell patients have neutrophilia, as they are prone to the bacterial infections. Lymphocytosis is asymptomatic; it is diagnosed by blood test and caused by an illness or other problems such as viral infections or tuberculosis. In the current study the $\mathrm{HbSC}$ patients had not any history of tuberculosis so their lymphocytosis may be due to viral infection.

Samir $\mathrm{K}$ and coworkers reported that $\mathrm{MCHC}$ is higher in $\mathrm{HbC}$ patients than healthy individuals [23]. Similarly, the current data showed that SC subjects' erythrocytes were smaller than normal $\mathrm{RBC}$ with a higher $\mathrm{MCHC}$ value than other family members (Table 1). Other RBC indices were within the normal range for Sudanese individuals [12].

$\mathrm{HbF}$ at 4.4 to $4.6 \%$ in the $\mathrm{HbSC}$ cases was higher than levels reported in Sudanese patients with HbSS [24]. Of the HbAS cases, $\mathrm{HbF}$ was very low in the sister and her brother, but it was $0.2 \%$ in the mother. This is a lower percentage than in father (Table 2).

The prevalence of abnormal $\mathrm{Hbs}$ can be reduced by the premarital diagnostic screening of carriers with hereditary disorders. At present, the majority of people in Sudan have no recorded medical history and there are currently no 


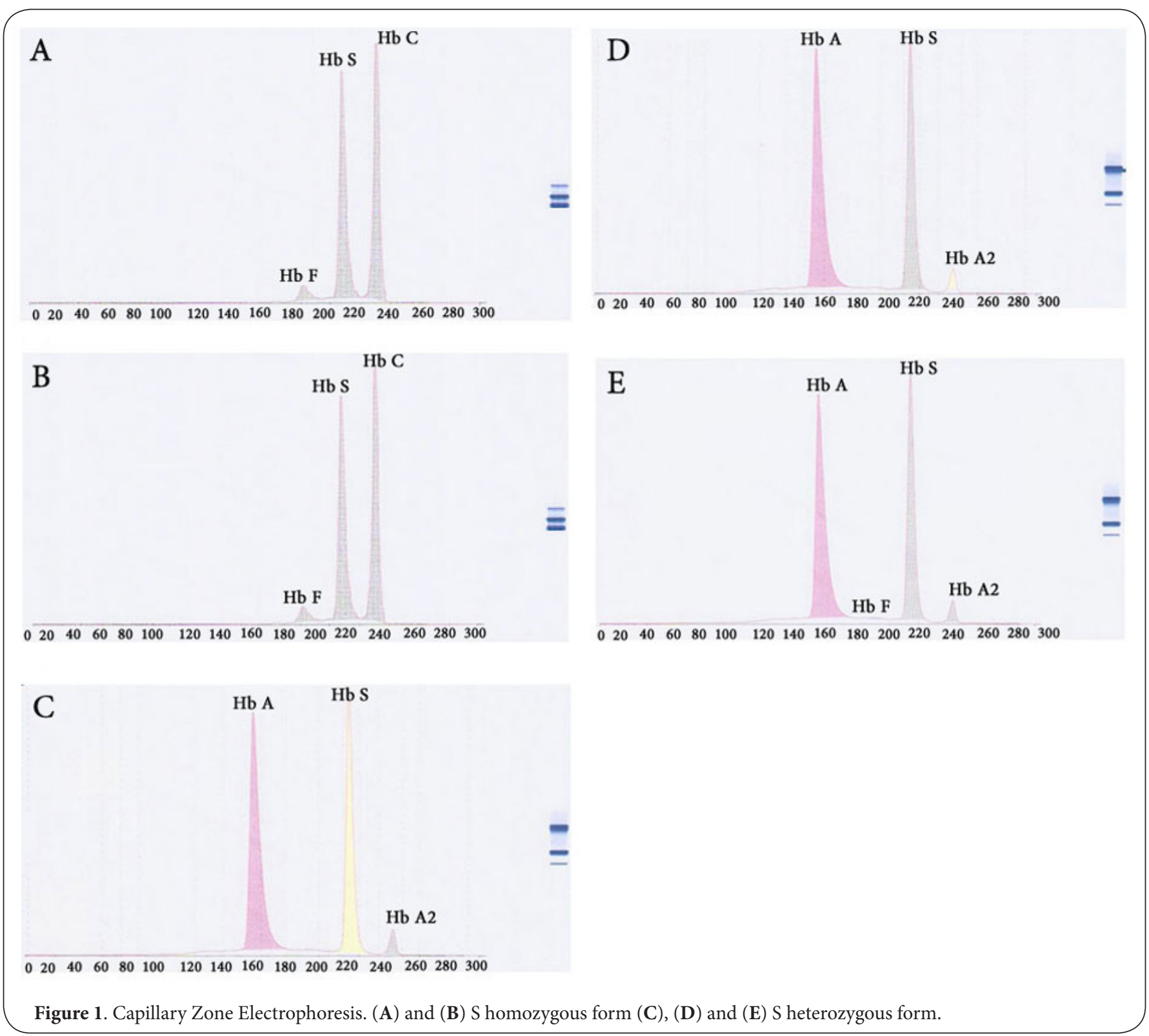

screening facilities. One outcome from the data reported here is that following birth, all babies undergo either CE or CE-HPLC screening for $\mathrm{Hb}$ variants, and have their medical history recorded.

CC individuals have mild chronic haemolytic anaemia with frequent splenomegaly and abnormal blood smears containing microspherocytes and target cells [25]. A pathogenetic correlate of these findings is the increased mean corpuscular haemoglobin concentration (MCHC) of CC cells, which leads to intracellular crystallization of $\mathrm{HbC}[26,27]$. Although AC individuals do not show these changes, both $A C$ and $C C$ cells are significantly more rigid than their $A A$ counterparts $[26,28]$. Because AC and CC cells can support high parasitemias in vivo, the malaria protective mechanism of $\mathrm{HbC}$ may involve elements of both perturbed RBC physiology and non sterile immunity. In conclusion, two courses of action involving health education and screening are suggested as ways of avoiding the risk of $\mathrm{Hb}$ abnormality. Health education is recommended for all known carriers of $\mathrm{Hb}$ abnormalities and patients suitable for screening programmes should include pregnant women and their newly born children. Screening should also include the genetic counselling of carriers $[29,30]$.

SCA and $\mathrm{HbC}$ disease are also continuing problems in Sudan, and this not unexpected because Sudanese patients with SCA were previously seen more in paediatric clinics than in adult clinics [12]. 
Elderdery et al. Hematology and Leukemia 2014,

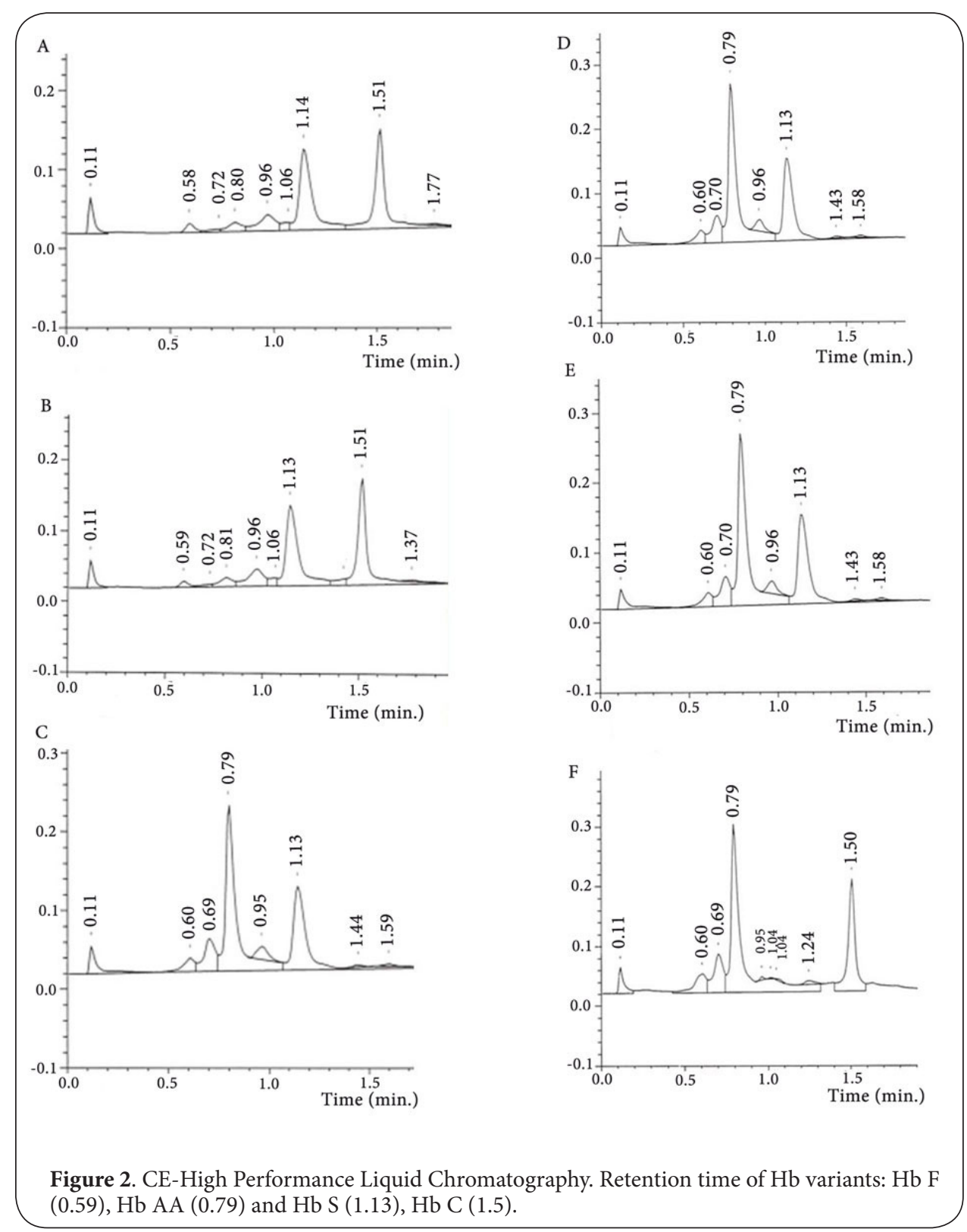

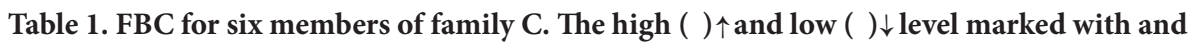
arrow to each parameter respectively.

\begin{tabular}{llllllllll}
\hline Patients & Hb g/dl & PCV\% & RBC 10 $/ \mathbf{L}$ & WBC10 $/ \mathbf{L}$ & PLt10 $/ \mathbf{L}$ & MCVfL & $\begin{array}{l}\text { MCH } \\
\text { pg }\end{array}$ & $\begin{array}{l}\text { MCHC } \\
\text { gldl }\end{array}$ & $\begin{array}{l}\text { RDW } \\
\text { fL }\end{array}$ \\
\hline A & $10 \downarrow$ & $28.5 \downarrow$ & $3.2 \downarrow$ & $17 \uparrow$ & $358 \uparrow$ & 87 & 30.8 & 35.1 & $65.8 \uparrow$ \\
B & $7.6 \downarrow$ & $22.4 \downarrow$ & $2.5 \downarrow$ & $18.3 \uparrow$ & 187 & 87 & 29.6 & 33.9 & $79.6 \uparrow$ \\
C & 11.4 & 34 & 3.9 & 7.1 & 265 & 82 & 28.7 & & \\
D & $9.6 \downarrow$ & $26.5 \downarrow$ & $3.0 \downarrow$ & $16.7 \uparrow$ & $339 \uparrow$ & 84 & 30.1 & 34.2 & $67.9 \uparrow$ \\
E & $11.3 \downarrow$ & $33.2 \downarrow$ & $3.8 \downarrow$ & $14.3 \uparrow$ & 448 & 86.9 & 29.6 & 34 & 53 \\
F & -- & -- & -- & -- & -- & -- & -- & -- & -- \\
\hline
\end{tabular}

Two sisters family C had high WBC and RDW, whereas their Hb, PCV and RBC count were low. Similarly, Hb, PCV and RBC were low in their mother but her RDW and WBC was normal. 
Elderdery et al. Hematology and Leukemia 2014,

http://www.hoajonline.com/journals/pdf/2052-434X-2-2.pdf

Table 2. Level of haemoglobin F.

\begin{tabular}{|c|c|c|c|c|c|c|}
\hline Patients & Hb A & HbS & HbC & HbA2 & $\mathrm{HbF}$ & Others \\
\hline A & $\begin{array}{l}? \dagger \\
40\end{array}$ & $\begin{array}{l}47.5 \dagger \\
42.5\end{array}$ & $\begin{array}{l}48.1 \dagger \\
45.3\end{array}$ & $\begin{array}{l}? \dagger \\
1.4 \%\end{array}$ & $\begin{array}{l}4.4 \dagger \\
3.9 \stackrel{1}{1}\end{array}$ & $\begin{array}{l}? \dagger \\
2.9 \Leftrightarrow\end{array}$ \\
\hline B & $\begin{array}{l}? \dagger \\
3.20\end{array}$ & $\begin{array}{l}46.9 \dagger \\
42.4\end{array}$ & $\begin{array}{l}49.1 \dagger \\
44.8 \dagger\end{array}$ & $\begin{array}{l}? \dagger \\
1.3 \omega\end{array}$ & $\begin{array}{l}4.2 \dagger \\
3.90\end{array}$ & $\begin{array}{l}? \dagger \\
4.4 \%\end{array}$ \\
\hline $\mathrm{C}$ & $\begin{array}{l}53.9 \dagger \\
50.7\end{array}$ & $\begin{array}{l}42.6 \dagger \\
41.4\end{array}$ & $\begin{array}{l}? \dagger \\
? \stackrel{9}{?}\end{array}$ & $\begin{array}{l}3.5 \dagger \\
3.1 \propto\end{array}$ & $\begin{array}{l}? \dagger \\
? 9\end{array}$ & $\begin{array}{l}? \dagger \\
4.8 \%\end{array}$ \\
\hline $\mathrm{D}$ & $\begin{array}{l}55.5 \dagger \\
51.5\end{array}$ & $\begin{array}{l}42.4 \dagger \\
41.3\end{array}$ & $\begin{array}{l}? \dagger \\
?+\end{array}$ & $\begin{array}{l}2.1 \dagger \\
2.6 \%\end{array}$ & $\begin{array}{l}? \dagger \\
0.7 \%\end{array}$ & $\begin{array}{l}? \dagger \\
3.9\end{array}$ \\
\hline $\mathrm{E}$ & $\begin{array}{l}53.9 \dagger \\
50.5 \%\end{array}$ & $\begin{array}{l}42.8 \dagger \\
41.8\end{array}$ & $\begin{array}{l}? \dagger \\
? \stackrel{0}{0}\end{array}$ & $\begin{array}{l}3.5 \dagger \\
2.9 \triangleq\end{array}$ & $\begin{array}{l}0.2 \dagger \\
0.5 \otimes\end{array}$ & $\begin{array}{l}? \dagger \\
4.2 \%\end{array}$ \\
\hline $\mathrm{F}$ & $\begin{array}{l}---\dagger \\
47.5\end{array}$ & $\begin{array}{l}----\dagger \\
? \boldsymbol{s}\end{array}$ & $\begin{array}{l}---\dagger \\
45.2\end{array}$ & $\begin{array}{l}---\dagger \\
1.7 \$\end{array}$ & $\begin{array}{l}---{ }^{-} \\
2.62\end{array}$ & $\begin{array}{l}---\dagger \\
32\end{array}$ \\
\hline
\end{tabular}

$\dagger=$ Capillary Electrophoresis result; $=$ CE-High

Performance Electrophoresis result; others= unknown $\mathrm{Hb}$ variants.

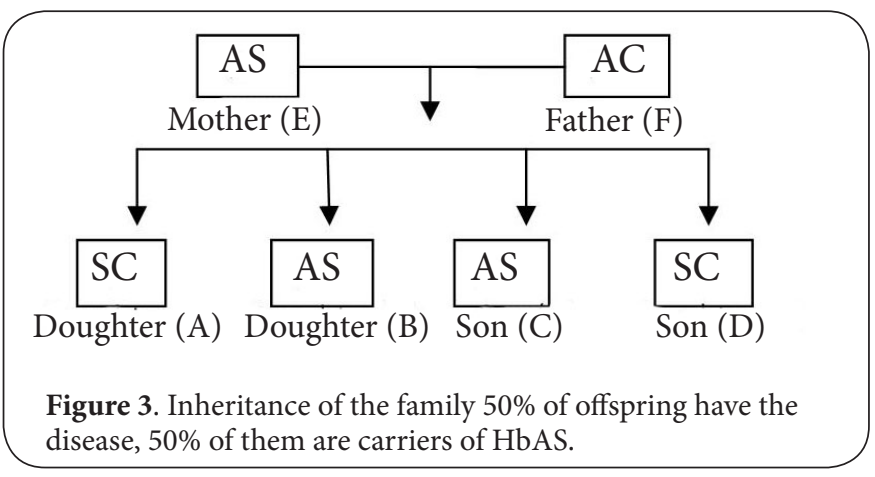

Competing interests

The authors declare that they have no competing interests.

Authors' contributions

\begin{tabular}{|l|c|c|c|c|}
\hline Authors' contributions & AYE & BAM & SHALM & JM \\
\hline Research concept and design & -- & -- & $\checkmark$ & $\checkmark$ \\
\hline Collection and/or assembly of data & $\checkmark$ & -- & -- & -- \\
\hline Data analysis and interpretation & $\checkmark$ & $\checkmark$ & -- & -- \\
\hline Writing the article & $\checkmark$ & -- & -- & -- \\
\hline Critical revision of the article & -- & -- & -- & $\checkmark$ \\
\hline Final approval of article & -- & $\checkmark$ & -- & -- \\
\hline Statistical analysis & $\checkmark$ & -- & $\checkmark$ & -- \\
\hline
\end{tabular}

Acknowledgement

The authors wish to thank Dr Mirgani Ali and staff of the Haematology Department at the Military hospital in Omdurman for their assistance with this study. Financial support from Faculty of Medicines of the Imam Mahadi, Ministry of Higher education, Sudan, and from the University of Portsmouth, School of Pharmacy and Biomedical Sciences, UK, is greatly acknowledged.

Publication history

EIC: Evangelos Terpos, University of Athens School of Medicine, UK. Received: 16-Sep-2013 Revised: 03-Dec-2013

Accepted: 16-Dec-2013 Published: 07-Mar-2014

\section{References}

1. Hiernauz J, Linhard J, Livingstone FB, Neel JV, Robinson A and Zuelzer WW. Date on the occurrence of hemoglobin $C$ and other abnormal hemoglobins in some African populations. Am J Hum Genet. 1956 Sep; 8:138-50. | Article

2. Bunn HF. Pathogenesis and treatment of sickle cell disease. $N$ Engl J Med. 1997; 337:762-9. | Article | PubMed

3. Ballas SK, Lewis CN, Noone AM, Krasnow SH, Kamarulzaman E and Burka ER. Clinical, hematological, and biochemical features of $\mathrm{Hb}$ SC disease. Am J Hematol. 1982; 13:37-51. | Article | PubMed

4. Angastiniotis $M$, Modell B, Englezos $P$ and Boulyjenkov V. Prevention and control of haemoglobinopathies. Bull World Health Organ. 1995; 73:37586. | PubMed Abstract | PubMed Full Text

5. Makani J, Williams TN and Marsh K. Sickle cell disease in Africa: burden and research priorities. Ann Trop Med Parasitol. 2007; 101:3-14. | Article I PubMed

6. Modiano D, Luoni G, Sirima BS, Simpore J, Verra F, Konate A, Rastrelli E, Olivieri A, Calissano C, Paganotti GM, D'Urbano L, Sanou I, Sawadogo A, Modiano $G$ and Coluzzi M. Haemoglobin C protects against clinical Plasmodium falciparum malaria. Nature. 2001; 414:305-8. | Article | PubMed

7. Masmas TN, Garly ML, Lisse IM, Rodriques A, Petersen PT and Birgens $\mathrm{H}$. Inherited hemoglobin disorders in Guinea-Bissau, West Africa: a population study. Hemoglobin. 2006; 30:355-64. | Article | PubMed

8. Rihet $\mathrm{P}$, Flori $\mathrm{L}$, Tall F, Traore AS and Fumoux F. Hemoglobin $\mathrm{C}$ is associated with reduced Plasmodium falciparum parasitemia and low risk of mild malaria attack. Hum Mol Genet. 2004; 13:1-6. | Article | PubMed

9. Aidoo M, Terlouw DJ, Kolczak MS, McElroy PD, ter Kuile FO, Kariuki S, Nahlen BL, Lal AA and Udhayakumar V. Protective effects of the sickle cell gene against malaria morbidity and mortality. Lancet. 2002; 359:1311-2. | Article | PubMed

10. Checchi F, Cox J, Balkan S, Tamrat A, Priotto G, Alberti KP and Guthmann JP. Malaria epidemics and interventions, Kenya, Burundi, southern Sudan, and Ethiopia, 1999-2004. Emerg Infect Dis. 2006; 12:1477-85. | Article | PubMed Abstract | PubMed Full Text

11. Nourein AB, Abass MA, Nugud AH, El Hassan I, Snow RW and Noor $A M$. Identifying residual foci of Plasmodium falciparum infections for malaria elimination: the urban context of Khartoum, Sudan. PLOS One. 2011; 6:e16948. | Article | PubMed Abstract | PubMed Full Text

12. Elderdery AY, Mohamed BA, Karsani ME, Ahmed MH, Knight G and Cooper AJ. Hemoglobinopathies in the Sudan. Hemoglobin. 2008; 32:323-6. | Article | PubMed

13. Lauden RJ IS. Sickling in South West Kordufan. Sud Med J. 1990; 8:207 17. | Article

14. Omer A, Ali M, Omer AH, Mustafa MD, Satir AA and Samuel AP. Incidence of G-6-PD deficiency and abnormal haemoglobins in the indigenous and immigrant tribes of the Sudan. Trop Geogr Med. 1972; 24:401-5. I PubMed

15. Ibrahim SA and Mustafa D. Sickle-cell haemoglobin $O$ disease in a Sudanese family. Br Med J. 1967; 3:715-7. | Article | PubMed Abstract | PubMed Full Text

16. Marouf R, D'Souza T M and Adekile AD. Hemoglobin electrophoresis and hemoglobinopathies in Kuwait. Med Princ Pract. 2002; 11:38-41. I Article I PubMed

17. Kutlar F. Diagnostic approach to hemoglobinopathies. Hemoglobin. 2007; 31:243-50. | Article | PubMed

18. Waneesorn J, Panyasai S, Kongthai K, Singboottra P and Pornprasert S. Comparison between capillary electrophoresis and high performance liquid chromatography for detection and quantification of $\mathrm{Hb}$ constant spring [Hb CS; alpha142, Term-->GIn (TAA>CAA IN alpha2)]. Hemoglobin. 2011; 35:338-45. | Article | PubMed

19. Henderson SJ, Fishlock K, Horn ME, Oni L and Bellingham AJ. Neonatal screening for haemoglobin variants using filter paper-dried blood specimens. Clin Lab Haematol. 1991; 13:327-34. | Article | PubMed 
Elderdery et al. Hematology and Leukemia 2014,

20. Bayoumi RA, Taha TS and Saha N. A study of some genetic characteristics of the Fur and Baggara tribes of the Sudan. Am J Phys Anthropol. 1985; 67:363-70. | Article | PubMed

21. Mohammed AO, Attalla B, Bashir FM, Ahmed FE, El Hassan AM, Ibnauf G, Jiang W, Cavalli-Sforza LL, Karrar ZA and Ibrahim ME. Relationship of the sickle cell gene to the ethnic and geographic groups populating the Sudan. Community Genet. 2006; 9:113-20. I Article I PubMed

22. Stevens MC, Maude GH, Beckford M, Grandison Y, Mason K, Serjeant BE, Taylor B, Topley JM and Serjeant GR. Haematological change in sickle cell-haemoglobin $\mathrm{C}$ disease and in sickle cell-beta thalassaemia: a cohort study from birth. Br J Haematol. 1985; 60:279-92. | Article | PubMed

23. Ballas SK and Kocher W. Erythrocytes in $\mathrm{Hb}$ SC disease are microcytic and hyperchromic. Am J Hematol. 1988; 28:37-9. | Article I PubMed

24. Elderdery AY, Mills J, Mohamed BA, Cooper AJ, Mohammed AO, Eltieb N and Old J. Molecular analysis of the beta-globin gene cluster haplotypes in a Sudanese population with sickle cell anaemia. Int J Lab Hematol. 2012; 34:262-6. | Article | PubMed

25. Smith EW and Krevans JR. Clinical manifestations of hemoglobin C disorders. Bull Johns Hopkins Hosp. 1959; 104:17-43. I PubMed

26. Charache S, Conley CL, Waugh DF, Ugoretz RJ and Spurrell JR. Pathogenesis of hemolytic anemia in homozygous hemoglobin $C$ disease. J Clin Invest. 1967; 46:1795-811. | Article | PubMed Abstract | PubMed Full Text

27. Araujo JT, Batissoco AC and Bodemeier L. "In vivo" and "in vitro" demonstration of hemoglobin C crystals in non-splenectomized patients. Rev Inst Med Trop Sao Paulo. 1999; 41:235-8. | Article | PubMed

28. Booth F and Mead SV. Resistance to lysis of erythrocytes containing haemoglobin C--detected in a differential white cell counting system. J Clin Pathol. 1983; 36:816-8. I Article I PubMed Abstract I PubMed Full $\underline{\text { Text }}$

29. Cao A, Galanello R and Rosatelli MC. Prenatal diagnosis and screening of the haemoglobinopathies. Baillieres Clin Haematol. 1998; 11:215-38. | Article I PubMed

30. Baysal E. Hemoglobinopathies in the United Arab Emirates. Hemoglobin. 2001; 25:247-53. | Article | PubMed

\section{Citation:}

Elderdery AY, Mohamed BA, Hamad Al- Mijalli S

and Mills J. First recorded case of haemoglobin SC

in sudan. Hematol Leuk. 2014; 2:2.

http://dx.doi.org/10.7243/2052-434X-2-2 